GULTURAL HISTORY OF MODERN WAR

\title{
Linda Maynard
}

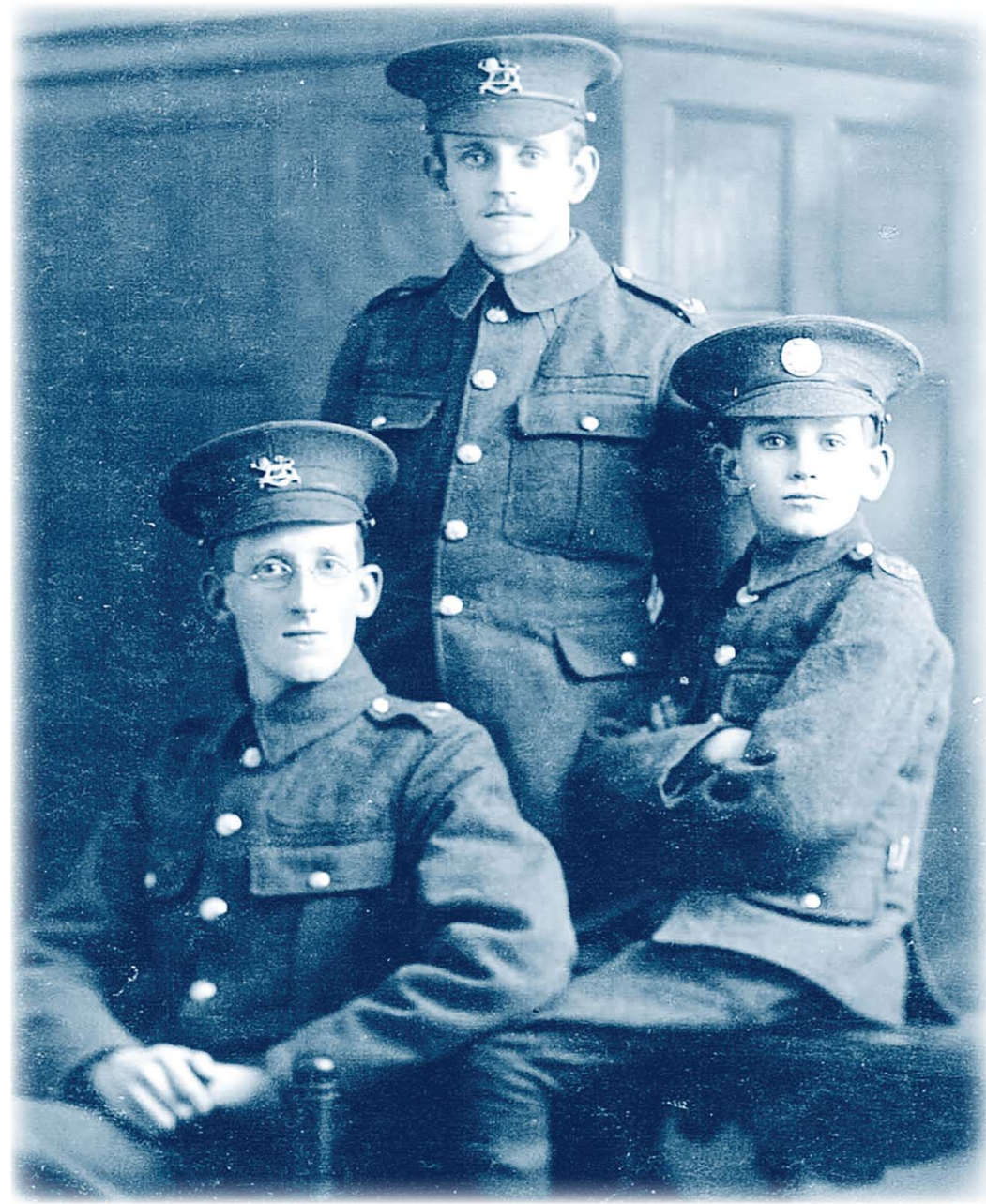

\section{BROTHERS IN THE GREAT WAR}

SIBLINGS, MASCULINITY AND EMOTIONS 


\section{Brothers in the Great War}

\section{MANCHESTER \\ 1824}

Manchester University Press 


\section{Cultural History of Modern War}

Series editors Ana Carden-Coyne, Peter Gatrell, Max Jones, Penny Summerfield and Bertrand Taithe

\section{Already published}

Carol Acton and Jane Potter Working in a world of hurt: Trauma and resilience in the narratives of medical personnel in warzones

Michael Brown, Anna Maria Barry and Joanne Begiato (eds) Martial masculinities: Experiencing and imagining the military in the long nineteenth century

Quintin Colville and James Davey (eds) A new naval history

James E. Connolly The experience of occupation in the Nord, 1914-18: Living with the enemy in First World War France

Lindsey Dodd French children under the Allied bombs, 1940-45: An oral history

Peter Gatrell and Liubov Zhvanko (eds) Europe on the move: Refugees in the era of the Great War

Grace Huxford The Korean War in Britain: Citizenship, selfhood and forgetting

Duy Lap Nguyen The unimagined community: Imperialism and culture in South Vietnam

Lucy Noakes Dying for the nation: Death, grief and bereavement in Second World War Britain

Juliette Pattinson, Arthur McIvor and Linsey Robb Men in reserve: British civilian masculinities in the Second World War

Spyros Tsoutsoumpis A history of the Greek resistance in the Second World War: The people's armies 


\section{Brothers in the Great War}

\section{Siblings, masculinity and emotions}

Linda Maynard

Manchester University Press 
The right of Linda Maynard to be identified as the author of this work has been asserted by her in accordance with the Copyright, Designs and Patents Act 1988.

This electronic version has been made available under a Creative Commons (CC-BY-NC-ND) licence, thanks to the support of Knowledge Unlatched, which permits noncommercial use, distribution and reproduction provided the author and Manchester University Press are fully cited and no modifications or adaptations are made. Details of the licence can be viewed at https://creativecommons.org/licenses/by-nc-nd/4.0/

Published by Manchester University Press Altrincham Street, Manchester M1 7JA www.manchesteruniversitypress.co.uk

British Library Cataloguing-in-Publication Data A catalogue record for this book is available from the British Library

ISBN 9781526146144 hardback

First published 2021

The publisher has no responsibility for the persistence or accuracy of URLs for any external or third-party internet websites referred to in this book, and does not guarantee that any content on such websites is, or will remain, accurate or appropriate.

Cover image: George Denis Davies, David Charles Ivor Davies and James Edgar Davies, October 1914. (Reproduced with permission of the Davies family and Hereford History).

Typeset by Servis Filmsetting Ltd, Stockport, Cheshire 